Research Article

DOI: $10.24327 / \mathrm{JJRSR}$

\title{
EFFECT OF FRIED JUNK FOOD ON THE PH OF THE ORAL CAVITY
}

\author{
Subeeksha VS
}

DOI: http://dx.doi.org/10.24327/ijrsr.2017.0803.0099

\section{ARTICLE INFO}

\section{Article History:}

Received $18^{\text {th }}$ December, 2016

Received in revised form $10^{\text {th }}$

January, 2017

Accepted $06^{\text {th }}$ February, 2017

Published online $28^{\text {th }}$ March, 2017

\begin{abstract}
Topic: Effect of fried starch food (junk food) on the $\mathrm{pH}$ in the oral cavity Aim: To find the effect of fried starch food (junk food) on the $\mathrm{pH}$ level in the oral cavity

Background: Maintaining a good $\mathrm{pH}$ balance in the mouth allows a healthy balance of good and bad bacteria. Certain food such as sugary beverages, snacks, and some grains increase the acidity in the mouth. The $\mathrm{pH}$ of mouth can change dramatically with the type of food we eat. The saliva can help neutralise the acid but eating acidic food can increase the acidity of the saliva.

Reason: This study is used to assess the relationship between $\mathrm{pH}$ and
\end{abstract}

effect of fried starch food (junk food) on the oral cavity

Copyright (C) Subeeksha VS, 2017, this is an open-access article distributed under the terms of the Creative Commons Attribution License, which permits unrestricted use, distribution and reproduction in any medium, provided the original work is properly cited.

\section{INTRODUCTION}

Although there are a wide range of foods that individuals intake on a daily basis from different parts of the globe, they are not aware of the advantages and disadvantages which can harm their bodies. The $\mathrm{pH}$ level in the body affects health. Studies have shown that lower, or acidic, $\mathrm{pH}$ levels are associated with a greater risk of serious health conditions including type 2 diabetes, heart disease, and obesity. Its just not that, it affects the oral cavity too. All the food we eat and the drinks we drink change mouth $\mathrm{pH}$. A healthy mouth is a non-acidic, neutral, or alkaline mouth, with a $\mathrm{pH} 7.0$ or above. Tooth roots begin to dissolve as this $\mathrm{pH}$ gets a tiny bit below neutral (at $\mathrm{pH}$ 6.5) and, when acidity levels dip to $\mathrm{pH} 5.5$ or lower teeth will erode, become discoloured, and be at risk for cavities. All acidity weakens teeth, but it is the amount of time that acids are in contact with teeth that determines the severity of the damage. Erosion and decay are worse when people sip drinks or nibble acidic foods. The strong acidity of citrus fruits, juices and wines ( $\mathrm{pH} 2.2$ or lower) to the alkaline $\mathrm{pH}$ of chicken soup and salty nuts ( $\mathrm{pH} 8.5$ or higher), mouth $\mathrm{pH}$ can fluctuate wildly. Balance is important when deciding on foods for regulating the $\mathrm{pH}$ of the mouth. While having a mouth that is too low on the $\mathrm{pH}$ scale can put one at a higher risk for cavities. Regulating the $\mathrm{pH}$ in the mouth will also help reduce the bacteria in our mouths, thereby reducing our risk for cavities, gum disease, and tooth decay. Sugars commonly found in foods including sucrose (tablesugar), glucose, fructose, lactose and cooked starches are the sources for Bacterial feed. Foods such as fried potatoes, high masala content food, candies, sodas, pastas, and breads, and even natural fruits, give bacteria in the mouth more fuel to produce lactic acid which is the acid that causes tooth decay. Consuming foods that balance the alkalinity of saliva may be a method for creating an unfavourable environment for bacteria to thrive. When $\mathrm{pH}$ drops, bacteria that produce lactic acid thrive. Brushing regularly will clear away food residue and starve the bacteria, keeping its growth in check.

\section{MATERIALS AND METHODS}

The study was conducted among the students of saveetha dental college and hospitals, Chennai, India. The study population consists of 30 individuals within the age group of 15-25 years. They for assessed for change in salivary $\mathrm{pH}$ before and after consumption of fried starch food (junk food). The saliva of the individuals were collected before consumption and the $\mathrm{pH}$ were taken a note of. This cycle was repeated after their consumption of fried starch foods. The changes were checked after a time interval of 10-15mins.

\section{RESULTS}

The $\mathrm{pH}$ of the saliva was initially neutral i.e 7 before consumption of fried starch food. After consuming the salivary $\mathrm{pH}$ was found to be in the range between 5-6. The present study suggests that there is an decrease in the salivary $\mathrm{pH}$ after consuming the fried starch food (junk food). The lesser the $\mathrm{pH}$ the greater the acidity of the salivary $\mathrm{pH}$. At a $\mathrm{pH}$ of 5.5 the teeth begin to demineralise and putting at a risk for cavities. 


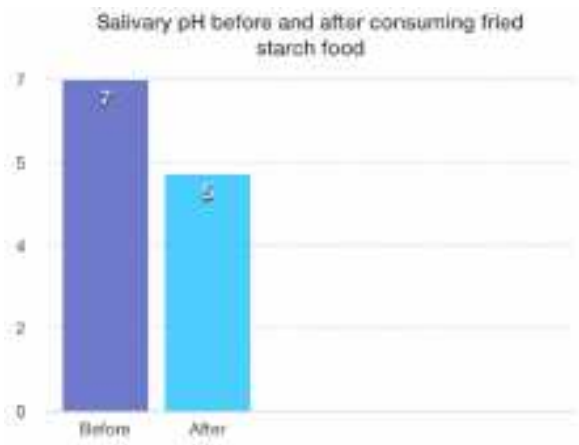

\section{DISCUSSION}

Your oral $\mathrm{pH}$ is a reflection of the balance between various intrinsic and extrinsic factors that can either be protective and damaging to your teeth. The $\mathrm{pH}$ scale goes from 1 to 14,1 being the most acidic, 14 being the most alkaline, and 7 being neutral (like most water). A pH of 5.5 is an important $\mathrm{pH}$ level for teeth as the teeth begin to dissolve or demineralise at a $\mathrm{pH}$ in the mouth below 5.5. At a pH above 5.5, the teeth begin to remineralise. Tooth decay can occur when the $\mathrm{pH}$ level in the mouth is 5.5. When we consume acidic foods and drinks, the $\mathrm{pH}$ within the mouth decreases and can cause the $\mathrm{pH}$ in the dental plaque to fall rapidly below 5.0. This happens through the production of acids as the bacteria metabolise the ingested nutrients. When the mouth undergoes dramatic or long-lasting periods of low $\mathrm{pH}$, it can cause cavity-causing bacteria to grow. The saliva can help neutralise the acid, but eating acidic foods can increase the acidity of the saliva. If the $\mathrm{pH}$ takes a long time to neutralize in the mouth, it may give bad bacteria enough time to wreak havoc on the teeth and gums. Typically it may take a few minutes or a few hours for the $\mathrm{pH}$ to neutralise. An acidic mouth is an optimal environment for bad bacteria to grow, and if given the time and the ability, it can cause tooth decay. People with acidic saliva often experience dental problems because their own saliva damages teeth. These folks wonder why they have uncontrollable cavities, broken fillings, gum recession or sensitivity, despite their efforts to brush and floss. Dental plaque that is kept at a $\mathrm{pH}$ of 7.0 or greater does not experience this shift in the bacterial species to acid uric and acidogenic (cavity-causing) bacteria even during exposure to sugar. If the $\mathrm{pH}$ in the mouth can be maintained at a neutral or alkaline $\mathrm{pH}$, regardless of sugar, food, or acidic drink consumption, the healthy bacteria within the dental plaque biofilm will not die and the shift to cavity-causing bacteria will not occur.
Balance is important when deciding on foods for regulating the $\mathrm{pH}$ of the mouth. While having a mouth that is too low on the $\mathrm{pH}$ scale can put one at a higher risk for cavities, consuming only foods with only high $\mathrm{pH}$ can be too much of a good thing. Consumption of the proper vitamins and nutrients required for good health, and good oral health, is most important.

\section{CONCLUSION}

In conclusion, the study shows that there is a decrease in $\mathrm{pH}$ of saliva after consuming fried starch food (junk food). Frequent consumption of such food decreases the oral $\mathrm{pH}$ and significantly increases the development of plaques and dental caries. The $\mathrm{pH}$ level in the mouth affects the health of our teeth and gums. And the way to control the $\mathrm{pH}$ is through the foods we eat. By focusing on the general health benefits of an alkaline diet, we create a ripple effect for dental health. Regulating the $\mathrm{pH}$ in the mouth will also help reduce the bacteria in our mouths, thereby reducing our risk for cavities, gum disease, and tooth decay

\section{Reference}

1. Baliga, Sharmila, Sangeeta Muglikar, and Rahul Kale. "Salivary pH: A Diagnostic Biomarker." Journal of Indian Society of Periodontology 17.4 (2013): 461-465. PMC. Web. 15 Feb. 2017.

2. TOLENTINO, Elen de Souza, Luiz Eduardo Montenegro CHINELLATO, and Olinda TARZIA. "Saliva and Tongue Coating $\mathrm{pH}$ before and after Use of Mouthwashes and Relationship with Parameters of Halitosis." Journal of Applied Oral Science 19.2 (2011): 90-94. PMC. Web. 15 Feb. 2017.

3. Fiyaz, Mohamed et al. "Association of Salivary Calcium, Phosphate, $\mathrm{pH}$ and Flow Rate on Oral Health: A Study on 90 Subjects." Journal of Indian Society of Periodontology 17.4 (2013): 454-460. PMC. Web. 15 Feb. 2017.

4. Aas, Jørn A. et al. "Defining the Normal Bacterial Flora of the Oral Cavity." Journal of Clinical Microbiology 43.11 (2005): 5721-5732. PMC. Web. 15 Feb. 2017.

5. Hans, Rinki et al. "Effect of Various Sugary Beverages on Salivary pH, Flow Rate, and Oral Clearance Rate amongst Adults." Scientifica 2016 (2016): 5027283. PMC. Web. 15 Feb. 2017.

6. Surdacka, Anna, Krystyna Strzyka3a, and Anna Rydzewska. "Changeability of Oral Cavity Environment." European Journal of Dentistry 1.1 (2007): 14-17. Print.

\section{How to cite this article:}

Subeeksha VS.2017, Effect of Fried Junk Food on The Ph of The Oral Cavity. Int J Recent Sci Res. 8(3), pp. 16209-16210. DOI: http://dx.doi.org/10.24327/ijrsr.2017.0803.0099 